\title{
PERAN PONDOK PESANTREN TERHADAP PENDIDIKAN KARAKTER
}

\author{
Moh. Abdullah \\ STAI Miftahul Ulum Pamekasan \\ Email : aabsaen661@gmail.com
}

\begin{abstract}
Absolute education becomes the foundation of every human being that must be internalized in every soul as a human soul, it must be a good and good measure of a person. One of the institutions that play an important role in ahlak education is pondok pesantren. The weight of the boarding school in boarding school education is a human challenge, the behavior is praiseworthy and virtuous, making attitudes or character in the world of boarding school education, an important goal and the ultimate goal of education, which is delivered by people who have morality in addition to knowledge. Therefore, the moral position is very important in the world of boarding school education. Pondok pesanntren can not only convey material through classical books, but is more than just a practice in daily life, so that character education is easily ingrained through the souls of the santri as objects in the character education in the boarding school environment. Until now, education is one of the main education that continues to be maintained, not displaced by anything while continuing to try trials and acanman from various sectors. Therefore, Islamic boarding school educational institutions continue to get good responses from the community. This journal tries to reveal the vital role of Islamic boarding schools in character education. Trying to reveal the boarding school in the process of planting education is right from the beginning until this moment.
\end{abstract}

Keywords: Pesantren, Character Education.

\section{Pendahuluan}

Akhir-akhir ini minat para masyarakat terhadap pondok pesantren semakin tinggi terhadap keberlangsungan pendidikan para putranya, hal ini terlihat dengan semakin terus bertambahnya volume santri baru setiap tahunnya dipesantren-pesantren. Menjadikan pesantren sebagai lembagaa pendidikan untuk menempa pendidikan para masyarakat bukan tampa alasan. Hal ini karena anggapan masyarakat, pendidikan yang aman saat ini dari berbagai ancaman yang mengancam masa depan adalaah pondok pesantren. Hal ini melihat fenomena yang terjadi di bumi persada ini adalah dekadensi moral diberbagai dimensi dan sektor, tawuran di mana-mana, pergaulan bebas, narkoba serta

Ulumuna: Jurnal Studi Keislaman

Vol.5 No.2 Desember 2019:

P-ISSN 2442-8566

E-ISSN 2685-9181 
budaya alay yang terus merongrong moral dan etika para generasi muda. Dan terus melemahnya di sektor ahlakul karimah atau pendidikan karakter yang disebabkan oleh berbagai faktor. Berdasarkan hal ini membuat para orang tua berbondong-bondong memondokkan anaknya kepesantren, karena di pesantren titik tekan pengajarannya adalah pendidikan karakter, disamping ilmu agama sebagai pendidikan titik tekan khusus, pendidikan karakter menjadi sebuah konsentrasi yang keberadaanya tidak pernah tergantikan semenjak awal sampai detik ini, pondok pesantren mampu menjaga dari berbagai godaan. Serta penekanan terhadap pendidikan karakter dipesantren diajarkan secara sistematis, dan berjanjang sesuai dengan tahapan dan tingkatannya, tidak kalah pentingnya di pesantren juga langsung diperaktekan dalam kegiatan sehariharinya, dan juga menjadi sebuah penilain pertama yang didahulukan dibandingkan lainnya.

Ditambah kebanyakan pondok pesantren menerapkan pendidikan intgritas, hal ini dibuktikan dengan banyak pondok pesantren mendirikan pendidikan formal seperti, SMA, SMK, dan Perguruan Tinggi, membuat ketertarikan para orang tua semakin meningkat. Karena bukan pendidikan agama saja akan tetapi pendidikan umum mereka jugaa dapatkan, hal ini sulit didapatkan di luar pesantren, ditambah pengakuan dari pemerintah seperti adanya hari santri Nasional, serta banyak beasiswa yang khusus untuk para santri, sehingga menjadi pemicu semangat orang tua untuk memondokkan putranya kepesantren ditambah karena barang tentu pendidikan karakter menjadi pokok pembelajaran di pondok pesantren.

Sudah menjadi kesadaran bersama bahwa dunia pendidikan merupakan cara yang telah dilakukan umat manusia sepanjang kehidupannya untuk menjadi sarana dalam melakukan transmisi dan transformasi baik nilai maupun ilmu pengetahuan. Demikian strategisnya dunia pendidikan sebagai sarana transmisi dan transformasi nilai dan ilmu pengetahuan ini, maka dalam rangka menanamkan dan mengembangkan karakter bangsa ini, tidak lepas pula dari peran yang dimainkan oleh dunia pendidikan. Pendidikan karakter penting bagi kehidupan manusia, maka peran yang dimainkan dunia pendidikan haruslah tidak sekadar menunjukkan pengetahuan moral, tetapi juga mencintai dan mau melakukan tidakan moral. ${ }^{1}$

Karena pada dasarnya karakter merupakan nilai-nilai perilaku manusia yang berhubungan dengan Tuhan Yang Maha Esa, diri sendiri, sesama manusia,

\footnotetext{
${ }^{1}$ Ajat Sudrajat, Mengapa Pendidikan Karakter, Jurnaal Pendidikan Karakter, Tahun 1, Nomor 1, Oktober 2011, 47.
} 
lingkungan dan kebangsaan yang terwujud dalam pikiran, sikap, perasaan, perkataan, dan perbuatan berdasarkan normanorma agama, hukum, tata krama, budaya dan adat istiadat. ${ }^{2}$

Pembentukan karakter harus dilakukan secara sistematis dan berkesinambungan yang melibatkan aspek knowledge, feeling, loving dan action. Pembentukan karakter dapat diibaratkan sebagai pembentukan seseorang menjadi body builder (binaragawan) yang memerlukan "latihan otototot akhlak" secara terus-menerus agar menjadi kokoh dan kuat ${ }^{3}$

Salah satu institusi pendidikan yang disinyalir telah lama menerapkan pendidikan karakter adalah pondok pesantren. Sistem Pendidikan Nasional yang indigenous Indonesia, bahkan dipandang oleh banyak kalangan mempunyai keunggulan dan karakteristik khusus dalam mengaplikasikan pendidikan karakter bagi anak didiknya (santri). ${ }^{4}$ Pandangan demikian tampaknya berasal dari kenyataan bahwa: pesantren lebih mudah membentuk karakter santrinya karena institusi pendidikan ini menggunakan sistem asrama yang memungkinkannya untuk menerapkan nilai-nilai dan pandangan dunia yang dianutnya dalam kehidupan keseharian santri. ${ }^{5}$

\section{Tinjauan Tentang Pondok Pesantren}

Setiap pesantren pada umumnya memiliki pondokan, pondok dalam pesantren pada dasarnya merupakan dua kataa yang sering penyebutannyaa tidak dipisahkan menjadi "Pondok Pesantren", yang berarti keberadaan pondok dalam pesantren merupakah wadah pengemblengan, pembinaan dan pendidikan serta pengajaran ilmu pengetahuan. ${ }^{6}$ Pondok pesantren merupakan lembaga pendidikan Islam yang mempunyai peranan penting dalam sejarah Islam di Indonesia, khususnya di pulau jawa dan madura. Pondok pesantren jika di Aceh disebut rangkang atau meunasah, sedangkan di Sumatra Barat disebut surau. ${ }^{7}$ Kata pondok berasal dari bahasa Arab "fundug" yang berarti "hotel atau

\footnotetext{
${ }^{2}$ Siti Farida, Pendidikan Karakter Perspektif Islam, Kabilah, Vol. 1 No. 1 Juni 2016, 199

${ }^{3}$ Asmaun Sahlan. Pendidikan Karakter dalam Perspektif Islam (Kajian Penerapan

Pendidikan Karakter di Lembaga Pendidikan Islam, 2013). El-HiKMAH, 9(2),50.

${ }^{4}$ Imam Syafe'I, Pondok Pesantren: Lembaga Pendidikan Pembentukan Karakter ; Al-

Tadzkiyyah: Jurnal Pendidikan Islam, Volume 8, No I 2017, 62.

${ }^{5}$ Makmun, H. Pembentukan Karakter Berbasis Pendidikan Pesantren: Studi di Pondok

Pesantren Tradisional dan Modern Di Kabupaten Ponorogo. Cendekia Vol.,.2014. 12, 20.

${ }^{6}$ M. Bachri Ghazali, Pesantren Berwawasan Lingkungan, (Jakaarta, CV Prasti), 20.

${ }^{7}$ Binti Maunah, Traduisi Intelektuaal Santri Dalaam Tantangan dan Hambaatan

Pendidikan Pesantren di Masa Depan, (Yogyakaarta Teras 2009), 16.
} 
asrama" sedangkan kata pesantren berasal dari kata santri dengan awalan "pe" dan akhiran "an" yang berarti tempat tinggal santri." Sedangkan KH. Abdurrahman Wahid, pondok pesantren adalah komplek dengan lokasi yang umumnya terpisah dari kehidupan sekitarnya. Dalam komplek itu terdiri dari beberapa buah bangunan : rumah pengasuh, sebuah surah atau masjid dan asrama tempat tinggal santri. ${ }^{10}$ berbagai pendapaat di atas pondok pesantren merupakaan sebuah wadah pendidikan manusia seutuhnyaa sebagai operasionalisasi dari pendidikan yakni didalam terjadi proses belajar mengajar, antara para santri dengan kyai. Serta sebuah lembaga sebagaai tempat penggemblengan, pembinaan, pengaajaran berbagai ilmu pengetahuan

Istilah pesantren berasal dari kata santri yang diberi awalan "pe" dan akhiran "an" yang dikarenakan pengucapan kata itu kemudian berubah menjadi terbaca "en" (pesantren), yaitu sebutan untuk bangunan fisik atau asrama dimana para santri bertempat. ${ }^{11}$ Kata pesantren berasal dari kata "santri" yang mendapat awalan pe dan akhiran an, menjadi pesantrian yang berarti tempat berdiam para santri, sehingga kata pondok dan pesantren mempunyai kemiripan pengertian. ${ }^{12}$ Penamaan kata "pesantren" untuk menyebut lembaga pendidikan Islam ini tidak lepas dari kata "santri". ${ }^{13}$ Menurut Azyumardi Azra pesantren dalam pengertian konvensional adalah lembaga pendidikan Islam tradisional untuk tafaqquh fiddin yang menganut ideology kegamaan "Aswaja," Ahli Sunnah Wa al-Jamaah. Dalam pengertian itu, pesantren adalah lembaga pendidikan yang sepenuhnya bertujuan untuk mendalami ilmu agama Islam. ${ }^{14}$ Dari penjelasan ini bisa diartikan bahwa pesantren adalah lembaga pendidikan Islam untuk mendalami agama Islam yang menitik beratkan terhadap pendalaman paham Ahli Sunnah Wa al-Jamaah (ASWAJA).

Pesantren sebagai sebuah institusi memiliki suguhan materi yang unik, ia mengajarkan tentang keislaman baik yang berkaitan dengan substansi Islam

\footnotetext{
${ }^{8}$ Zamakhsayari Dhofier, Tradisi Pesantren Studi Tentang Pandangan Hiduo Kyai, (Jakarta : LP3ES), 8

${ }^{9}$ Ibid, 12.

${ }^{10}$ Abdurrahman Wahid, Menggerakkan tradisi esaai-esai pesantren, (Yogyakarta : LkiS, 2001),3.

11 Ahmad Muhakamurrohman, Pesantren Santri,Kiai,dan Tradisi, Vol. 12, No.2,JuliDesember 2014, 111.

12 Mohammad Muchlis Solichin, Keberlangsungan dan Perubahan Pendidikan Pesantren di Tengah Arus Modernisasi Pendidikan (Surabaya: CV. Salsabila Putra Pratama, 2013), 9.

${ }^{13}$ Masyhuri Mochtar, Dinamika Kajian Kitab Kuning di Pesantren (Pasuruan: Pustaka Sidogiri, 1434), 17.

${ }^{14}$ Badrus Sholeh dkk, Budaya Damai Komonitas Pesantren (Jakarta: Pustaka LP3ES Indonesia,2007), 147.
} 
itu sendiri maupun yang berkenaan dengan alat atau metode untuk memahami Islam. Materi keislaman yang diajarkan pada lembaga ini antara lain adalah Fiqh, Ilmu Hadist, Ilmu al-Qur'an, dan Ilmu Alat, seperti Nahwu dan Sharraf. ${ }^{15}$ Pesantren tidak hanya mengandung unsur keaslian (Indigenous) Indonesia, tetapi juga mengandung makna keislaman, ${ }^{16}$ Identitas pesantren hanya sebagai lembaga pendidikan, penyiaran agama Islam, reproduksi ulama, pemeliharaan Islam tradisional ${ }^{17}$

\section{Sejarah dan Perkembangan Pesantren.}

Para ahli sejarah berbeda pendapat tentang asal usul lembaga pendidikan yang disebut pesantren. ${ }^{18}$ Terdapat perbedaan pendapat diantaranya dikemukan oleh Menurut Zamakhsyari Dhofier bahwa pesantren di Jawa sejak bentuknya yang paling tua merupakan kombinasi antara madrasah dan pusat kegiatan tarekat. ${ }^{19}$ Menurut Bruinessen, menyatakan bahwa di Kalimantan, Sulawesi, dan Lombok lembaga semacam pesantren baru ada setelah abad ke-20. ${ }^{20}$ Pondok pesantren muncul pertama kali di Indonesia pada abad ke-16 M, yakni terdapat di Ampel Denta dalam asuhan Sunan Ampel. Pada waktu itu, beliau mengkader santri-santrinya untuk menyebarkan ajaran Islam ke seluruh pelosok tanah air, bahkan ada yang ditugaskan hingga ke negara-negara tetangga. ${ }^{21}$ Menurut Nurcholis Madjid berdasarkan data Departemen Agama, pesantren tertua di Indonesiai ialah Pondok Pesantren Luhur Dondong Semarang, yang didirikan pada tahun 1906 oleh Kiai Syafi'I Pijoro Negoro- konon kiai ini adalah salah seorang komandan pasukan Sultan Agung saat menyerbu Batavia. ${ }^{22}$

Sebagai unit lembaga pendidikan dan sekaligus lembaga dakwah, pesantren pertama kali dirintis oleh Syekh Maulana Malik Ibrahim pada 1399 M yang berfokus pada penyebaran agama Islam di Jawa. Selanjutnya, tokoh yang berhasil mendirikan dan mengembangkan pesantren adalah Raden Rahmad (Sunan Ampel). ${ }^{23}$

${ }^{15}$ Sarkawi, Sistem Pembelajaran Pondok Cilik Maktab Nubdzatul Bayan Mambaul Ulum Bata-Bata Pamekasan, Tadris Volome 7 Nomor 2 Desember 2012, 269

${ }^{16}$ Mundzier Saputra, Perubahan Orientasi Pondok Pesantren Salafiyah Terhadap Perilaku Keagamaan Masyarakat (Jakarta:Asta Buana Sejahtera,2009), 1.

17 Dawam Rahardjo, Pergulatan Dunia Pesantren, Membangun dari Bawah,(Jakarta:P3M,1985),1.

${ }^{18}$ Mundzier Saputra, Perubahan Orientasi Pondok Pesantren Salafiyah Terhadap Perilaku Keagamaan Masyarakat,,53.

${ }^{19}$ Zamakhsyari Dhofier, Tradisi Pesantren Studi Tentang Pandangan Hidup Kiai, (Jakarta: LP2ES, 1995).92.

${ }^{20}$ Martin Van Bruinessen, Kitab Kuning Pesantren dan Tarekat, (

${ }^{21}$ Ahmad Muhakamurrohman, Pesantren Santri,Kiai,dan Tradisi, 112.

${ }^{22}$ Nurcholish Madjid, Bilik-Bilik Pesantren, (Jakarta :Dian Rakyat,),133.

${ }^{23}$ Abd. Halim Soebahar, Modernisasi Pesantren (Yogyakarta: YKiS, 2013), 33. 
Pesantren juga merupakan lembaga pendidikan tertua di negeri ini, karena ia lahir sebelum Indonesia mencapai kemerdekaanya tahun 1945. Bahkan dalam catatan sejarah disebutkan, bahwa pesantren memiliki andil besar atas kemerdekaan negeri ini. ${ }^{24}$ Pesantren lebih awal tumbuh dan berkembang di Indonesia jauh sebelum Indonesia merdeka. Bahkan, lembaga pendidikan tradisional ini telah berdiri di sejumlah daerah terkenal. ${ }^{25}$ Pesantren sudah ada sejak masa awal penyebaran Islam di Indonesia. ${ }^{26}$ Pondok pesantren tetap menjadi lembaga pendidikan dan keagamaan Islam tertua di Indonesia, dan perkembangannya berasal dari masyarakat yang melingkupinya. ${ }^{27}$

Pesantren pertama didirikan di Kembang Kuning, yang waktu itu hanya dihuni oleh tiga orang santri, yaitu Wiro Suroyo, Abu Hurairoh dan Kiai Bangkuning. Pesantren tersebut kemudian dipindahkan ke kawasa Ampel di seputar Delta Surabaya, karena inilah pulalah Raden Rahmad akhirnya di kenal dengan sebutan Sunan Ampel. Selanjutnya, putra dan santri dari Sunan Ampel mulai mendidirikan beberapa pesantren baru, seperti pesantren Giri oleh Sunan Giri, Pesantren Demak oleh Raden Fatah dan pesantren Tuban oleh Sunan Bonang. Fungsi pesantren pada awalnya hanyalah sebagai media islamisasi yang memadukan tiga unsur, yaitu ibadah untuk menanamkan iman, tabligh untuk menyebarkan Islam dan ilmu serta ama untuk mewujudkan kegiatan sehari-hari dalam kehidupan masyarakat. ${ }^{28}$

Dalam perkembangannya, ketika modernisasi pendidikan berupa hadirnya sistem sekolah dan diadopsi dalam pendidikan nasional, eksistensi pesantren mulai menghadapi penetrasi, baik dalam hal kelembagaan, kurikulum, maupun tradisi akademiknya. Dengan adanya surat keputusan bersama antara Menteri Pendidikan dan Kebudayaan, Menteri Agama, dan Menteri Dalam Negeri, disingkat dengan SKB 3 Menteri , 24 Maret 1975, secara resmi sistem pendidikan Islam Indonesia telah menjadi subsistem pendidikan nasional. ${ }^{29}$ Sejak era tahun 1970-an inilah merupakan Awal dari perkenalan pendidikan pesantren dengan berbagai kursus ketrampilan dan memasuki tahun 1990-an, dinamika pendidikan pesantren memperlihatkan perkembangan yang lebih dinamis, yakni dengan menyelenggarakan pendidikan formal madrasah yang

\footnotetext{
${ }^{24}$ Masyhuri Mochtar, Dinamika Kajian Kitab Kuning di Pesantren, 15.

${ }^{25}$ Affandi Moctar, Kitab Kuning dan Tradisi Akademik Pesantren, (Jawa Barat: Pustaka Isfahan,2009), 13 .

${ }^{26}$ Mundzier Saputra, Perubahan Orientasi Pondok Pesantren Salafiyah Terhadap Perilaku Keagamaan Masyarakat,55.

${ }^{27}$ Kafrawi, Pembaharuan Sistim Pendidikan Pondok Pesantren Sebagai Usaha Peningkatan Prestasi Kerja dan Pembinaan Kesatuan Bangsa, (Jakarta: PT. Cemara Indah,1978), 18.

${ }^{28}$ Abd. Halim Soebahar, Modernisasi Pesantren (Yogyakarta: YKiS,2013),33.

${ }^{29}$ Mastuhu, Dinamika Sistem Pendidikan Pesanten: Suatu Kajian tentang Unsur dan Nilai Sistem Pendidikan Pesantren, (Jakarta: INIS,1994),61.
} 
integral dengan pendidikan pesantren. $^{30}$ Selanjutnya sesuai dengan perkembangan zaman, konsep pesantren pun mengalami dinamika dari yang sangat sederhana sampai mewah, dari salafiyah sampai khalafiyah,atau tradisional sampai modern, dan atau konvensional (tradisional) sampai kontemporer (masa kini). ${ }^{31}$

\section{Elemen-elemen dalam Pesantren}

Pondok, masjid, santri, pengajaran kitab Islam klasik dan kyai adalah lima elemen dasar tradisi pesantren. Ini berarti bahwa lembaga pengajian yang telah berkembang hingga memiliki kelima elemen tersebut berubah statusnya menjadi pesantren. Di seluruh Indonesia, orang biasanya membedakan kelaskelas pesantren dalam tiga kelompok, yaitu pesantren kecil, menengah, dan besar. ${ }^{32}$ Karakteristik tradisi pesantren misalnya dikemukakan oleh Zamakhsyari Dhofier, yaitu pondok, masjid, pengajian kitab-kitab Islam klasik (kitab Kuning), santri dan kyai. ${ }^{33}$ Karakteristik yang sama dikemukakan oleh Departemen Agama, yaitu kyai sebagai pimpinan pondok pesantren, santri yang bermukim di asrama dan belajar kepada kyai, asrama sebagai tempat tinggal para santri, pengajian sebagai bentuk pusat pendidikan dan pusat kompleksitas kegiatan pondok pesantren. ${ }^{34}$

\section{a. Genialogi Penamaan Kyai}

Ditinjau dari asal usul kata, kiai berasal dari bahasa Jawa, ${ }^{35}$ yang digunakan untuk tiga jenis gelar yang berbeda, yaitu: Pertama, gelar kehormatan bagi barang-barang yang dianggap kramat, seperti: Kiai Garuda Kencana yang digunakan sebagai sebutan bagi kereta emas di Keraton Yogyakarta. Kedua, gelar kehormatan bagi orang-orang tua pada umumnya; Ketiga, gelar yang diberikan oleh masyarakat kepada ahli agama Islam yang memiliki atau menjadi pimpinan pesantren dan mengajar kitab-kitab Islam klasik kepada para santrinya. ${ }^{36}$

\footnotetext{
${ }^{30}$ Affandi Moctar, Kitab Kuning dan Tradisi Akademik Pesantren, (Jawa Barat: Pustaka Isfahan,2009), 14 .

${ }^{31}$ Mundzier Saputra, Perubahan Orientasi Pondok Pesantren Salafiyah,55.

${ }^{32}$ Zamakhsyari Dhofier, Tradisi Pesantren, 79.

${ }^{33}$ Zamakhsyari Dhofier, Tradisi Pesantren, 44-45

${ }^{34}$ Departemen Agama RI, Pembelajaran Pesantren: Suatu Kajian Komparatif, (Jakarta: Departemen Agama RI, 2002),8-9.

${ }^{35}$ Manfred Ziemek, Pesantren dalam Perubahan Sosial, Terjemahan Butche B. Soendjojo, (Jakarta: P3M, 1983),130.

${ }^{36}$ Zamakhsyari Dhofier, Tradisi Pesantren Studi Tentang Pandangan Hidup Kiai, (Jakarta: LP2ES,1995),93.
} 
Kebanyakan kyai hanya mengajarkan kitab kuning, tetapi tidak sedikit juga yang telah menambah khazanah Islam tradisional dengan mengarang kitab sendiri. ${ }^{37}$

Kiai merupaan elemen paling esensial dari suatu pesantren. Ia seringkali bahkan merupakan pendirinya. Sudah sewajarnya bahwa pertumbuhan suatu pesantren semata-mata bergantung pada kemampuan pribadi kiainya. ${ }^{38}$ Perang penting kiai dalam pendirian, pertumbuhan,perkembangan, dan pengurusan sebuah pesantren menunjukkan bahwa kiai merupakan unsur yang paling esensial. Watak dan keberhasilan pesantren banyak bergantung pada keahlian dan kedalaman ilmu, karisma dan wibawam serta ketrampilan kiai. Dalam konteks ini, pribadi kiai sangat menentukan sebab kiai adala tokoh sentral dalam pesantren. ${ }^{39}$ Keberadaan kiai sangat vital sekali didalam menentukan arah dan tujuan pesantren. Kiai pesantren adalah figure dengan kapasitas pribadi yang sarat dengan bobot kualitatif. Bobo kualitatif inilah yang menjadikan sosok kiai pesantren sebagai rujukan bagi masyarakat. ${ }^{40}$

Kiai merupakan sosok pemimpin agama yang dengan kepesantrenannya telah membuktikan sebagai pemimpin non formal dalam masyarakat Indonesia. Pengaruh seorang kiai sangat tergantung kepada ketinggian ilmu dan wibawa yang dimilikinya, yang seringkali ditandai dengan kebesaran dan kemajuan pesantren yang dimilikinya. ${ }^{41}$ Biasanya karisma kiai didasarkan kekuatan spiritual dan kemampuan memberi berkah karena hubungannya dengan alam gaib. Kuburannya pun dipercaya dapat memberikan berkah. ${ }^{42}$

\section{b. Konstruksi Terminologi Pondok}

Istilah pondok didefinisikan sebagai tempat tinggal sederhana bagi kyai bersama para santrinya. ${ }^{43}$ Pondok adalah tempat para santri menginap yang ada di lingkungan pesantren. Sistem asrama adalah salah satu ciri lembaga pendidikan pesantren yang terbukti dapat memberikan kesempatan kepada para santri untuk belajar secara intensif di bawah pengawasan kiai sebagai pengasuh pesantren. ${ }^{44}$ Selain untuk tempat tinggal santri, pondok juga digunakan sebagai tempat pengembangan keterampilan para santri agar siap hidup mandiri dalam masyarakat sesudah mereka tamat dari pesantren. Pesantren pada dasarnya

\footnotetext{
${ }^{37}$ Martin van Bruinessen, Kitab Kuning, Pesantren dan Tarekat, (Yogyakarta:Gading Publishing,2012),88.

${ }^{38}$ Zamarkhsyari Dhofier, Tradisi Pesantren (Jakarta: LP3ES, 2011), 93.

${ }^{39}$ Hasbullah, Kapita Selekta Pendidikan Islam, (Jakarta: Grafindo Persada, 1999),144.

${ }^{40}$ Acmad Fatoni, Peran Kyai Pesantren dalam Partai Politik, (Yogyakarta: Pustaka Pelajar,2007),3.

${ }^{41}$ Mohammad Muchlis Solichin, Keberlangsungan, 21.

${ }^{42}$ Martin van Bruinessen, Kitab Kuning, Pesantren dan Tarekat, (Yogyakarta:Gading Publishing,2012),88.

${ }^{43}$ Hasbullah, Kapita Selekta Pendidikan Islam, 142.

${ }^{44}$ Mohammad Muchlis Solichin, Keberlangsungan, 49.
} 
adalah sebuah asrama pendidikan Islam tradisional, di mana para santri tinggal dan belajar bersama di bawah bimbingan seorang kiai. Asrama para santri tersebut berada di kompleks pesantren, di mana sang kiai juga bertempat tinggal di situ dengan fasilitas utama berupa mushalla/langgar/masjid sebagai tempat ibadah, ruang belajar, dan pusat kegiatan keagamaan lainnya. Kompleks ini pada umumnya di kelilingi oleh pagar atau dinding tembok yang bergina untuk mengontrol keluar masuknya santri menurut peraturan yang berlaku di suatu pesantren. ${ }^{45}$ Pondok, asrama bagi para santri, merupakan ciri khas tradisi pesantren, yang membedakannya dengan sistem pendidikan tradisional di masjid-masjid yang berkembang di kebanyakan wilayah Islam di negara-negara lain. $^{46}$

Ada tiga alasan utama mengapa pesantren harus menyediakan asrama bagi para santri, pertama, kemasyahuran seorang kyai dan kedalaman pengetahuannya tentang Islam menarik santri-santri dari tempat-tempat yang jauh untuk berdatangan. Untuk dapat menggali ilmu dari kyai tersebut secara teratur dan dalam waktu yang lama, para santri harus meninggalkan kampung halamannya dan menetap di dekat kediaman kiai dalam waktu lama. Kedua, hampir semua pesantren berada di desa-desa, di mana tidak ada model koskosan seperti di kota-kota Indonesia pada umumnya dan juga tidak tersedia perumahan (akomodasi) yang cukup untuk dapat menampung santri-santri. Dengan demikian, perlu ada asrama khusus bagi para santri. Ketiga, ada sikap timbal balik antara kyai dan santri, di mana para santri menganggap kyainya seolah-olah sebagai titipan Tuhan yang harus senantiasa dilindungi. Sikap timbal balik ini menimbulkan keakraban dan kebutuhan untuk saling berdekatan terus menerus. Sikap ini juga menimbulkan perasaan tanggung jawab di pihak kyai untuk dapat menyediakan tempat tinggal bagi para santri. ${ }^{47}$

\section{c. Terminologi Masjid}

Masjid merupakan elemen yang tak dapat dipisahkan dari pesantren dan dianggap sebagai tempat yang paling tepat untuk mendidik para santri, terutama dalam praktik sembahyang lima waktu, khutbah dan sembahyang Jum'ah, dan pengajaran kitab kitab Islam klasik. ${ }^{48}$ Selain untuk melaksanakan shalat lima waktu dan shalat Jum'at, masjid juga digunakan untuk mendidik para santri dan menyelenggarakan pengajaran kitab-kitab kuning, sebagai pusat pendidikan, masjid merupakan manifestasi universial dari sistem pendidikan Islam sebagaimana yang dilakukan oleh Rasulullah, para sahabat, dan orang-orang

\footnotetext{
${ }^{45}$ Abd. Halim Soebahar, Modernisasi Pesantren, 41.

${ }^{46}$ Zamakhsyari Dhofier, Tradisi Pesantren Studi Tentang, 81

${ }^{47}$ Ibid, $82-83$

${ }^{48}$ Zamakhsyari Dhofier, Tradisi Pesantren Studi Tentang, 85
} 
sesudahnya. Tradisi yang dipraktikkan Rasulullah di masjid terus dilesatarikan oleh kalangan pesantren. Para kyai selalu mengajar santri-santrinya di masjid. ${ }^{49}$ Kedudukan masjid sebagai pusat pendidikan dalam tradisi pesantren merupakan manifestasi universalisesme dari sistem pendidikan Islam tradisional. Lembagalembaga pesantren memelihara terus tradisi ini. Para kyai selalu mengajar muridmuridnya di masjid dan menganggap masjid sebagai tempat yang paling tepat untuk menanamkan disiplin murid. Seorang kyai yang ingin mengembangkan sebuah pesantren biasanya pertama-tama akan mendirikan masjid di dekat rumahnya. ${ }^{50}$

\section{d. Derivasi Penamaan Santri}

Kata santri berasal dari Bahasa Tamil yang berarti orang yang mengetahui buku-buku suci agama Hindu atau sarjana yang ahli kitab agama Hindu, atau ahli dalam buku-buku suci, ahli buku-buku ilmu pengetahuan. ${ }^{51}$ Mengenai asal-usul perkataan "santri" itu ada (sekurang-kurangnya) dua pendapat yang bisa kita jadikan acuan. Pertama, adalah pendapat yang mengatakan bahwa "santri" itu berasal dari perkataan "sastri", sebuah kata dari bahasa sansekerta, yang artinya melek huruf. Agaknya dulu, lebih-lebih pada permulaan tumbuhnya kekuasaan politik Islam di Demak, kaum santri adalah kelas "literary" bagi orang jawa. Ini disebabkan pengetahuan mereka tentang agama melalui kitab bertulisan dan berbahasa arab. Dari sini bisa kita asumsikan bahwa menjadi santri berarti juga menjadi tahu agama (melalui kitab-kitab tersebut). Atau paling tidak seorang santri itu bisa membaca al-Qur'an yang dengan sendirinya membawa pada sikap lebih serius dalam memandang agamanya. Kedua, adalah pendapat yang mengatakan bahwa perkataan santri sesungguhnya berasal dari bahasa Jawa, persisnya dari kata cantrik, yang artinya seseorang yang selalu mengikuti seorang guru kemana guru ini pergi menetap. ${ }^{52}$

Pendefinisian santri juga berkembang di kalangan santri dengan beberapa penafsiran atas makna "santri", seperti kata santri yang tersusun dari kata san yang merupakan kependekan dari "insan", dan kata tri yang bermakna tiga. Maksudnya, santri adalah insan yang memiliki tiga prinsip, yaitu Islam, Iman, dan Ihsan..$^{53}$ Disamping itu, ada definisi "santri" yang secara khas

\footnotetext{
${ }^{49}$ Mundzier Suparta, Perubahan Orientasi Pondok Pesantren, 61.

${ }^{50}$ Zamakhsyari Dhofier, Tradisi Pesantren Studi Tentang, 86

${ }^{51}$ Mohammad Muchlis Solichin, Keberlangsungan dan Perubahan Pendidikan Pesantren di Tengah Arus Modernisasi Pendidikan (Surabaya: CV. Salsabila Putra Pratama, 2013), 17

${ }^{52}$ Nurcholis Majid, Bilik-Bilik Pesantren: Sebuah Potret Perjalanan (Jakarta: Paramadina, 1997), 21-22.

${ }^{53}$ Masyhuri Mochtar, Dinamika Kajian Kitab Kuning di Pesantren, 17.
} 
menggambarkan hakikat identitas santri secara esensial, sebgai orang yang mempelajari dan mengamalkan ajaran-ajaran Islam secara konsisten. Definisi ini dikemukakan oleh KH. Hasani Nawawi Pondok Pesantren Sidogiri Pasuruan Jawa Timur. ${ }^{54}$

$$
\text { وحقيقة الحال. }
$$

Artinya: Berdasarkan peninjaun tindak langkabnya, "santri" adalah orang-orang yang berpegang teguh pada al-Qur'an, dan mengikuti Sunah Rasul, serta tegub pendirian. Ini adalah arti dengan bersandar pada sejarah dan kenyataan, yang tidak dapat diganti dan diubah selama-lamanya. Alloh Maha Mengetabui atas kebenaran sesuatu dan kenyataannya.

Secara generik santri di pesantren berarti seseorang yang mengikuti pendidikan di pesantren berarti seorang yang mengikuti pendidikan di pesantren, dan dapat dikatagorisasikan ke dalam du kelompok besar, yaitu santri mukim dan santri kalong. Santri mukim adalah mereka yang datang dari tempat yang jauh dan ingin berkonsentrasi secara baik, sehingga harus tinggal dan menetap di pondok (asrama) pesantren, sedangkan santri kalong adalah mereka yang berasal dari wilayah sekitar pesantren dan biasanya mempunyai kesibukankesibukan lain, tapi pulang-pergi dari dan ke rumah masing-masing. ${ }^{55}$ Pendapat yang menyatakan bahwa kata santri berasal dari bahasa sansekerta dinilai cukup dapat diterima mengingat para penyebar Islam pertama di Pulau Jawa - Maulana Malik Ibrahim berasal dari Gujarat (India). Ulama ini ditengarai mengadaptasi lembaga pendidikan sebelum Islam di Jawa - berupa padepokan yang digunakan para pendeta mengajar - dengan pola pendidikan di India yang dikenal pada saat itu. ${ }^{56}$

\section{e. Pengajaran Kitab Islam Klasik}

Pada masa lalu, kitab-kitab Islam klasik, terutama karangan-karangan ulama yang menganut paham Syafi'i, merupakan satu-satunya teks pengajaran formal yang diberikan dalam lingkungan pesantren. Tujuan utamanya ialah

\footnotetext{
${ }^{54}$ Ibid, 18 .

${ }^{55}$ Mundzier Saputra, Perubahan Orientasi Pondok Pesantren Salafiyah Terhadap Perilaku Keagamaan Masyarakat, (Jakarta:Asta Buana Sejahtera,2009),65.

${ }^{56}$ Mohammad Muchlis Solichin, Keberlangsungan, 10.
} 
untuk mendidik calon-calon ulama. Para santri yang tinggal di pesantren untuk jangka waktu pendek dan tidak bercita-cita menjadi ulama, bertujuan untuk mencari pengalaman dan pendalaman perasaan keagamaan kebiasaan ini dilaksanakan menjelang dan pada bulan Romadhon. Para santri yang tingga sementara ini mempunyai tujuan yang tidak sama dengan para santri yang tinggal bertahun-tahun di pesantren. Mereka inilah yang ingin menguasai berbagai cabang pengetahuan Islam dan mempunyai kuat untuk menjadi ulama. ${ }^{57}$

\section{Tipologi Pondok Pesantren.}

Pondok pesantren sebagai lembaga pendidikan Islam mengalami perkembangan bentuk sesuai dengan perubahan zaman, teruama sekali adanya dampak kemajuan ilmuu pengetahuan dan teknologi. Perubahan bentuk pesantren bukan berarti berarti sebagai pondok pesantren yang telah hilang kekhasannya. Dalam hal ini pondok pesantren tetap merupakan lembaga pendidikan Islam yang tumbuh dan berkembang dari masyarakaat untuk masyarakaat. ${ }^{58}$ Sejak awal pertumbuhannya, 'pondok pesantren memiliki bentuk yang beragam asehingga tidak ada suatu standarisasi khusus yang berlaku bagi pondok pesantren. Menurut M. shulton dan Moh. Khusnur Ridho dilihat dari segi kurikulum dan materi yang diajarkan, pondok pesantren dapat digolongkan ke dalam empat tipe, yaitu :

1. Pesantren yang menyelenggarakan pendidikan formal dalam menerapkan kurikulum Nasional, baik yang hanya memiliki sekolah keagamaan (MI, MTS, MA dan perguruan Tinggi Agama Islam) maupun yang juga memiliki sekolah umum (SMP, SMA, SMK dan PT Umum) seperti pondok pesantren tebuireng jombang pondok pesantren miftahul ulum panyeppen palengaan pamekasan.

2. Pesantren yang menyelenggarakan pendidikan Umum ke agamaan dalam bentuk madrasah dan mengajarkan ilmu-ilmu umum meski tidak menerapkan kurikulum pendidikan Nasional, seperti Pondok Moderen Gontor.

3. Pesantren yang hanya mengajarkan ilmu-ilmu agama dalam bentuk Madrasah diniyah saja, seperti pondok pesantren Gontor atau pondok pesantren Lirboyo Kediri.

${ }^{57}$ Zamakhsyari dofier, Tradisi,86

${ }^{58}$ M. Bahri Ghazali, Pesantren Berwawasan Lingkungan, (Jakarta : Cv Prasasti, 2002), 14. 
4. Pesantren yang hanya sekedar menjadi tempat pengajian. ${ }^{59}$

Dan secara faktual ada beberapa tipe pondok pesantren yang berkembang dalam masyarakat, yang meliputi :

\section{Pondok Pesantren Tradisional}

Pondok pesantren ini masih tetap mempertahankan bentuk aslinya dengan semata-mata mengajarkan kitab yang ditulis oleh utama abad ke 15 dengan menggunakan bahasa Arab. Pola pengajarannya dengan menerapkan sistem "halaqah" yang dilaksanakan di surau dan Masjid. Hakekat dari sistem pengajaran halaqah adalah penghapalan yang titik akhirnya dari segi metodologi cendrung kepada terciptanya santri yang menerima dan memiliki ilmu. ${ }^{60}$.

2. Pondok Pesantren Modern

Pondok pesantren ini merupakan pengembangan tipe pesantren karena orientasi belajarnya cendrung mengadopsi seluruh sistem belajar secara klasik dan meninggalkan sistem belajar tradisional. Penerapan sistem belajar modern ini terutamaa nampak pada penggunaan kelas-kelas belajar baik dalam bentuk madrasah maupun sekolah. Kurikulum yang dipakai adalah kurikulum sekolah atau madrasah yang berlaku secara nasional. Perbedaanya dengan sekolah dan madrasah terletak pada porsi pendidikan agama da bahasa Arab lebih menonjol sebagai kurikulum lokal. ${ }^{61}$ Dapat diartikan bahwa pondok pesantren modern bermetamorfosis dari pendidikan tradisional ke pesantren modren, adanaya penggunaan kurikulum yang terstruktur.

\section{Mengenal Pendidikan Akhlak}

Pendidikan merupakan langkah awal dalam proses memuliakan manusia melalui kegiatan belajar mengajar secara sistematis, terukur dan terarah dengan baik sehingga dapat mengolah segala potensi yang ada di dalam diri peserta didik juga dapat membentuk kepribadian peserta didik menjadi lebih baik yang pada

\footnotetext{
${ }^{59}$ M. Shulton dan Khusnurridho, Manajemen Pondok Pesantren dalam Persepektif Global, (Yogyakarta : LaksbangPressIndo, 2006),8.

${ }^{60}$ Mastuhu, Dinamika Sistem Pendidikan Pesantren Suautu Kajian Tentang Unsur dan Nilai Sistem Pendidikan Pesantren (Jakarta : INIS, 1994), 157.

${ }^{61}$ M. Bahri Ghazali, Pesantren Berwawasan Lingkungan, ( Jakarta : Cv Prasasti, 2002), 14.
} 
akhirnya menjadikan mereka sebagai manusia yang mulia dan berbudi luhur. Ini menjadi suatu penegasan bahwa pendidikan sebagai upaya untuk membimbing, mengarahkan dan mendewasakan peserta didik menjadi pribadi yang luhur baik dari perkataan, perbuatan, sikap maupun pikiran. Sebagaimana pengertian pendidikan menurut Kamus Besar Bahasa Indonesia yang mengatakan bahwa pendidikan ialah:" "Sebuah kata yang berasal dari kata dasar didik, dan diberi awalan men, menjadi mendidik, yaitu kata kerja yang artinya memelihara dan memberi latihan (ajaran). Pendidikan sebagai kata benda berarti suatu proses perubahan sikap dan tingkah laku seseorang atau kelompok orang dalam usaha mendewasakan manusia melalui upaya pengajaran dan latihan."

Senada dengan penjelasan di atas, Zahara Idris menambahkan bahwa makna education (pendidikan) ${ }^{63}$ adalah kumpulan semua proses yang memungkinkan seseorang mengembangkan segala kompetensinya, sikap-sikap, bentuk-bentuk tingkah laku yang bernilai positif di dalam masyarakat tempat ia hidup atau di lingkungan sekitarnya. Dengan mengembangkan kemampuan, sikap dan tingkah lakunya ini menjadikan dia seseorang yang memiliki kecakapan dalam hidup baik dari segi kognitif, afektif maupun psikomotoriknya. Kemudian penjelasan tersebut dikuatkan oleh Ahmad D. Marimba, ${ }^{64}$ bahwa pendidikan adalah sebuah proses bimbingan secara sadar oleh pendidik terhadap perkembangan jasmani dan ruhani peserta didik menuju terbentuknya kepribadian yang utama (cakap:optimal). Sehingga pendidikan tidak bisa dipisahkan dari subjek dan objek, yakni pendidik dan peserta didik yang menjadi kunci dari terlaksananya proses pendidikan dengan baik.

Dengan demikian, dapat disimpulkan bahwa pendidikan merupakan sebuah proses yang secara sistematis dan kontinu melakukan bimbingan, arahan, latihan, pengajaran dan pendampingan kepada peserta didik untuk meningkatkan kemampuan kognitif, afektif dan psikomotoriknya sehingga dapat menjadikan mereka pribadi yang baik, unggul, cakap dan berakhlak serta kreatif. Titik berat dalam sebuah pendidikan khususnya pendidikan di lingkungan pondok pesantren adalah upaya membentuk manusia yang mulia dengan kepribadian baik, tingkah laku terpuji dan berbudi luhur, sehingga sikap atau akhlak dalam dunia pendidikan menempati posisi yang penting dan menjadi sebuah tujuan akhir suatu pendidikan di lingkunagan pondok pesantren, yakni melahirkan manusia yang berakhlak di samping berilmu. Oleh karenanya, posisi akhlak begitu penting di lingkungan pondok pesantren, di lingkungan pondok

\footnotetext{
${ }^{62}$ W. J. S. Poerwadarminta, Kamus Besar Bahasa Indonesia (Jakarta: Balai Pustaka, 1985), 702.

${ }^{63}$ Zahara Idris, Pengantar Pendidikan I (Jakarta: Grasindo, 1992), 2

${ }^{64}$ Ahmad D. Marimba, Pengantar Filsafat Pendidikan Islam (Bandung: al Ma'arif, 1998), 19.
} 
pesantren ada istilah al-Adzal Qablal Ilmu ahlak dulu baru ilmu pengetahuan, pondok pesanntren menekankan ahlak al-Karimah menjadi pondasi utama, dan menjadi program priorritas dibandingkan lainnya, keberadaan ahlakul karimah menjadi pendidika nomor dua setelah pendidikan tauhi atau keesaaan kepada Allah SWT.

Akhlak merupakan salah satu di antara tiga kerangka dasar ajaran Islam yakni aqi $>$ dah, shari $>$ 'ah dan akhla $>\mathrm{q}$, yang juga mempunyai kedudukan penting. ${ }^{65}$ Aqi $>$ dah adalah representasi dari $\mathrm{I}<\operatorname{ma}>$ n $($ tauh $\} \mathrm{i}>$ d), syari'ah adalah representasi dari Isla $>\mathrm{m}$ (fiqi $>\mathrm{h}$ ) dan akhlak dari representasi dari ih $\} \mathrm{sa}>\mathrm{n}$ (tas $\}$ awuf) ${ }^{66}$. Yang ketiganya harus saling berkaitan, berhubungan dan bersinergi dalam kehidupan manusia agar ia berhasil menjadi hamba yang mulia di sisi Alla $>$ h swt. Iman sebagai landasan pokok bagi seseorang ketika sudah masuk agama Islam, sedangkan Islam merupakan aplikasi dari keimananan yang sudah menancap di dalam hati seorang hamba tersebut. Kemudian, ihsan adalah out put dari keimananan dan keislaman yang sudah dilakukan dan diamalkan secara baik. Tanpa nilai Iman dan Islam yang baik tidak akan mungkin melahirkan akhlak yang mulia. ${ }^{67}$ Wujudnya (akhlak) merupakan bentuk konkrit dari penerapan aqidah dan syariah secara benar. Selain itu, juga menjadi gambaran dari kualitas keimanan seorang mukmin. Ibnu Qayyim dalam fawaidnya menjelaskan bahwa perbuatan anggota badan dapat menjadi bukti keimanan seseorang selain nilai spiritualitas batinnya. Sebab, menurutnya iman memiliki dua bentuk, yakni zahir dan batin. Pertama, dapat berupa ungkapan lisan maupun perbuatan anggota badan. Sedangkan kedua, adalah kemantapan dan kepercayaan hati, ketundukan dan kecintaan. ${ }^{68}$ Namun demikian, makna z $\}$ ahir tersebut tidak akan mempunyai dampak positif (manfaat) manakala makna batinnya kosong, lalai dan jauh dari keimananan kepada Allah, meskipun tindakan dan pengorbanannya tersebut sangat besar serta berat. ${ }^{69}$ Hal tersebut

${ }^{65}$ Muhammad Sayyid Thanthawi, al Aqidah wa al Akhlaq (Mesir: Nahdhatu Mishra, t.th), 204.

${ }^{66}$ Imam Ghazali Said, Kitab-kitab Karya Ulama' Pembaharu: Biografi, Pemikiran dan Pergerakan (Surabaya: PT Duta Aksara Mulia, 2018), 148.

${ }^{67}$ Penjelasan di atas dapat digambarkan dengan contoh puasa. Puasa itu sebagai bagian rukun Islam dan itu wajib dilakukan oleh orang beriman saja. Hasil dari puasa yang dilakukan dengan baik tersebut akan menghantarkan seseorang ke derajat taqwa. Taqwa sebagai bentuk ihsan yang merupakan out put dari rasa Iman dan Islam seseorang kepada Allah swt. Sesuai dengan firman Allah swt: “ Wahai orang-orang yang beriman, diwajibkan kepada kalian untuk berpuasa sebagaimana diwajibkan kepada orang-orang sebelum kalian agar kalian bertaqwa” (QS. 2: 183)

${ }^{68}$ Imam Syamsuddin Abu Abdillah Ibnu Qayyim al Jauziyyah, al Fawa 'id (Beirut: Dar al Fikr, 1993), 93.

${ }^{69}$ Penjelasan Ibnu Qayyim di atas, sesuai dengan apa yang dijelaskan oleh al Qur'an 24:29 dan 25:23. "bahwa orang-orang yang melakukan kebaikan sebesar apapun, namun tidak 
mengindikasikan bahwa akhlak sebagai manifestasi dari implementasi aspek iman dan Islam seseorang yang menjadikannya sebagai manusia yang memiliki sikap terpuji, berprilaku mulia dan berakhlak baik. Manusia yang berakhlak baik merupakan manusia yang dekat dengan Allah swt, sehingga dapat dipastikan mereka yang dirinya dihiasi dengan akhlak al karimah adalah mereka yang mempunyai nilai keimanan yang kuat disertai nilai keIslaman yang matang. Melalui akhlak inilah seseorang akan digolongkan dengan orang yang bertaqwa (muttaqin), di samping mubsinin. ${ }^{70}$

Karena pada dasarnya al Qur'an dan al Hadith mementingkan akhlak. Kedua sumber ajaran Islam tersebut menekankan nilai-nilai seperti kejujuran, kesetiakawanan, persaudaraan, rasa sosial, keadilan, tolong menolong, pemurah, penyayang, kerahaman, bersih hati, berani, kesucian diri, hemat, menepati janji, disiplin, mencintai ilmu dan berpikiran lurus (jernih dalam berpikir). Nilai-nilai demikian itulah yang harus dimiliki oleh setiap Muslim, di mana nilai-nilai tersebut harus diinternalisasikan pada diri mereka sejak dini sehingga mendarah daging dalam dirinya dan membentuk sebuah kepribadian yang mulia. Kemudian, ibadah dalam Islam erat sekali hubungannya dengan pendidikan akhlak. Ibadah dalam al Qur'an dikaitkan dengan takwa, dan takwa berarti melaksanakan perintah Tuhan dan menjauhi larangan-Nya. perintah Tuhan berkaitan dengan perbuatan baik, sedangkan larangan-Nya berkaitan dengan perbuatan jahat (buruk). Sehingga ajaran Islam pada intinya adalah menjadikan umatnya menjadi manusia bertakwa yang digambrakan dengan kebaikan budi atau berakhlak mulia. ${ }^{71}$

Dengan demikian, untuk melahirkan akhlak yang baik diperlukan sebuah pendidikan. Melalui pendidikan inilah akan dilatih pembiasanpembiasan yang baik sampai pembiasan itu tertanam dalam dirinya dan dapat diaplikasikan ke dalam kehidupan sehari-hari. Dan hal ini dilakukan oleh pondok pesantren dengan cara penyampaian materi dan langsung aplikasi (praktek) dalam kehidupan sehari, di asrama di kelas dan disemua dimensi

ada satu titikpun dalam hatinya rasa keimnanan kepada sang Maha Pencipta, maka alamanamalan (kebajikan-kebajikan) yang telah mereka kerjakan bagaikan fatamorgana dan tidak akan mendapatkan sedikitpun balasan kebaikan dari-Nya." baca lengkapnya dalam Ibnu Kathir al Qurshi ad Damashqi, Tafsir al Qur'an al 'Azim, Tahqiq Mahmud Hasan (t.tp: Dar al Fikr, 1994), 381-383.

${ }^{70}$ Ini sesuai dengan firman Allah swt: “ Dan bersegeralah kamu mencari ampunan dari Tuhanmu dan mendapatkan surga yang luasnya seluas langit dan bumi yang disediakan bagi orang-orang yang bertakwa (muttaqin), yaitu orang-orang yang berinfaq baik di waktu lapang maupun sempit, dan orang-orang yang menahan amarahnya dan memaafkan kesalahan orang lain. Dan Allah mencintai orang yang berbuat kebaikan (muhsinin)." (QS. 3: 133).

${ }^{71}$ Baca lengkapnya dalam Harun Nasution, Islam Rasional (Bandung: Mizan, 1996), 57. 
kegiatan santri. Dalam merealisasikan hal tersebut dibutuhkan sebuah konsep pendidikan serta kitab ahlak sebagai materi ajar yang bermuara ke akhlak yang disebut dengan pendidikan akhlak.

Konsep pendidikan akhlak dalam pandangan Islam memiliki arti yang sangat penting, sehingga hampir setiap kehidupan manusia tidak pernah lepas dari akhlak. Pendidikan akhlak adalah tema sentral bagi pelaksanaan pendidikan, karena pendidikan akhlak ini merupakan asas dasar bagi manusia untuk berinteraksi dengan Allah ( $h$ \}abl min Alla $>b$ ) maupun dengan sesama manusia (b\}abl min al-na>s). Pendidikan akhlak memiliki peran besar terhadap peradaban manusia. Membangun suatu kebudayaan dan peradaban akan melestarikan atau mengharmonisasikan masyarakat itu sendiri. Namun, individu-individu penyusunnya tidak akan mampu mewujudkan semua kebudayaan itu, tanpa diimbangi dengan pendidikan. Kalau mengambil ikhtiar melalui pendidikan akhlak, maka akan terbentuk dan dipertahankan kepribadian (akhlak) yang dinamis. Kekuatan itu, yang nantinya akan mengarahkan manusia untuk selalu semangat dalam membangun kebaikan serta menjadikannya ajang perlombaan (fastabiqu $>$ al khaira $>$ t). dilingkungan pesantren tidak dianggap berilmu jika tidak memiliki ahlak, meski ilmunya sangat dasar, masih belum mumpuni didalam membaca kitab kuning dan memahaminya, maka tidak tidak dianggap alim (pintar), maka ablak selalu satu indikator dianggap sukses.

Peran pondok pesantren dalam pendidikan akhlak dalam memajukan peradaban dan kebudayaan berupa penghiasan jiwa individu-individu dalam wujud kebaikan. Ia akan memotivasi individu (santri) tersebut untuk mengaktualisasikan segenap potensinya dalam bentuk inovasi-inovasi terbaru. Inovasi terbaru ini, selain untuk dimanfaatkan dalam kehidupan sehari-hari, juga ditujukan untuk mengangkat nilai-nilai kemanusiaan. ${ }^{72}$ Menjadi suatu penegasan bahwa pendidikan akhlak sebagai upaya membangun manusia yang memiliki semangat dalam menebar kebaikan, kedamain, persatuan, dan harmonisasi kehidupan di dunia. Selain menjadikannya sebagai insan yang cerdas secara akademik (intelektual). Artinya, pendidikan akhlak tidak hanya menjadikan manusia yang cerdas secara akademik, tetapi juga manusia yang beradab dan berbudi luhur.

Pendidikan Akhlak merupakan dua istilah yang terdiri dari pendidikan dan akhlak. Pendidikan itu sendiri secara kebahasaan dari kata al tarbiyah adalah usaha menumbuhkan atau menggali segenap potensi fisik, psikis, bakat, minat, talenta dan berbagai kecakapan lainnya yang dimiliki manusia (peserta didik)

${ }^{72}$ Rosif, "Pendidikan Etika dan Kepribadian; Studi atas Pemikiran Sayyid Naquib al Attas dan Ibn Miskawayh", dalam Antologi Kajian Islam, ed. Husein Aziz, et al. (Surabaya: Pascasarjana UIN Sunan Ampel Surabaya, 2016), 59-60. 
atau mengaktualisasikan berbagai potensi manusia yang terpendam, kemudian mengembangkannya dengan cara merawat dan memupuknya dengan penuh sentuhan (dekapan) kasih sayang. ${ }^{73}$ Senada dengan itu, Ahmad Tafsir mengartikan pendidikan adalah usaha meningkatkan diri dalam segala aspeknya. Pengertian ini mencakup kegiatan pendidikan yang melibatkan guru (pendidik) maupun yang tidak melibatkan guru yakni mencakup pendidikan formal maupun non formal serta juga informal. Segi yang dibina dalam pendidikan ini adalah seluruh aspek kepribadian (akhlak). ${ }^{74}$ Sedangkan akhlak secara etimologi dalam bahasa Arab merupakan jama' dari kata 'kbuluq' yang mempunyai makna literal sifat, budi pekerti, dan watak. ${ }^{75}$ Dalam bahasa Inggris kata padanannya adalah ethiscs yang artinya sebuah tingkah laku baik atau moral. ${ }^{76}$ Dapat juga diartikan sebagai adat serta kebiasaan dalam bahasa Yunani disebut ethos, ethikos atau mores. ${ }^{77}$

Akhlak dalam segi istilah, dapat diartikan dengan gambaran batin manusia yang mempunyai kemungkinan sifat baik atau buruk. ${ }^{78}$ Hal ini mengisyaratkan sebenarnya akhlak mempunyai keterkaitan dengan hati (qalb) manusia yang kemudian terpancarkan (terealisasi) dalam sebuah sikap tingkah laku (perilaku) yang kemudian menjadi sebuah kebiasaan dan adat. ${ }^{79}$ Hal senada juga dijelaskan oleh Ibn Miskawaih dalam karyanya Tab\}dbibu al Akbla $>q$, bahwa yang disebut akhlak adalah keadaan jiwa yang mengajak atau mendorong seseorang untuk melakukan segala perbuatan tanpa harus dipikirkan dan diperhitungkan. Dengan pengertian, sikap yang keluar dari diri seseorang itu secara spontan dan berangkat dari keadaan jiwa yang merupakan sumber dari segala perbuatan baik atau buruk. Untuk itu, apabila jiwa diarahkan kepada yang baik (positif) maka akibatnya akan memunculkan perilaku yang baik, tetapi jika diarahkan ke buruk (negatif) maka akibatnya akan memunculkan perilaku yang buruk.

\footnotetext{
${ }^{73}$ Ibrahim Ashimat Muthawi'y, Ushul al Tarbiyah (Mesir: Dar al Ma'arif, 1983), 24. Lihat juga dalam Muhammmad Abd al Qadir Ahmad, al Jadid fiy al Tarbiyah al Islamiyah (Mesir: al Nahdlah al Mishriyah, 1989), 8.

${ }^{74}$ Ahmad Tafsir, Metodologi Pengajaran Agama Islam (Bandung: PT Remaja Rosdakarya, 2017), 6 .

${ }^{75}$ Jamil Shaliba, al-Mu'jam al Falsafi (Mesir: Dar al Kitab al Misri, 1978) Jilid I, 539. Lihat juga Luis Ma'luf, al Munjid fi al Lughah wa al- 'alam (Beirut: Dar al Masyriq, 2002), 194.

${ }^{76}$ Jonathan Crowther, Oxford Advanced Learner's Dictionary of Current English (New York: Oxford University Press, 1995), 393.

${ }^{77}$ Fakhry Majid, Ethical Theories in Islam (Leiden: E. J. Brill, 1991), 2.

${ }^{78}$ Jamaluddin bin Manz \}ur, Lisa>n al 'Arab (Beirut: Dar S \}a>dir, 1414 H), Jilid X, 86.

${ }^{79}$ Muh $\}$ ammad bin Ya'qu>b Miskawaih, Tah\}dhib al Akhla $>q$ wa Tahhi $>r$ al 'Ara $>q$ (t.tp: Maktabah al-Thaqa $>$ fah al Di>niyyah, t.t), 41.
} 


\section{Kesimpulan}

Pondok pesantren mempunyai peran vital di dalam pendidikan ahlak (karakter), karena tidak hanya mengajarkan tentang materi ajar kitab kunning saja, akan tetapi ditekankan agar dipraktekkan dalam kehidupan sehari-hari di dalam semua aktifitas kegiatan santri, bahkan kesuksesan seorang santri diukur dengan cara menilai ahlak yang dimilikinya, jika mempunyai ahlak maka dianggap alim dan sebagainya. Dilingkungan pesantren pendidikan ahlak merupakan salah satu program utama setelah pendidkan mengenai tauhid, pendidikan ahlak menjadi program unggulan untuk amalkan bahkan menjadi sebuah keharusan yang harus mendarah daging didalam semua kegiatan, mulai dari gerak gerik dan sebagainya. Untuk melahirkan sanntri yang berahlakul karimah pondok pesantren tidak hanya dengan cara menyampaikan materi saja akan tetapi langsung dipraktekkan, dan menjadi salah satu penilaiann didalam setiap evaluasi yang dikerjakan. Wa Allah a'lam bi al-Shawab.

\section{DAFTAR PUSTAKA}

Ajat Sudrajat, Mengapa Pendidikan Karakter, Jurnaal Pendidikan Karakter, Tahun 1, Nomor 1, Oktober 2011.

Ashimat Muthawi'y, Ibrahim. Usbul al Tarbiyah (Mesir: Dar al Ma’arif, 1983), 24. Lihat juga dalam Muhammmad Abd al Qadir Ahmad, al Jadid fiy al Tarbiyah al Islamiyah. Mesir: al Nahdlah al Mishriyah, 1989.

Bruinessen, Martin van. Kitab Kuning, Pesantren dan Tarekat, Yogyakarta:Gading Publishing,2012.

Crowther, Jonathan. Oxford Advanced Learner's Dictionary of Current English. New York: Oxford University Press, 1995.

Departemen Agama RI, Pembelajaran Pesantren: Suatu Kajian Komparatif, (Jakarta: Departemen Agama RI, 2002.

D. Marimba, Ahmad. Pengantar Filsafat Pendidikan Islam. Bandung: al Ma'arif, 1998.

Dhofier, Zamakhsayari. Tradisi Pesantren Studi Tentang Pandangan Hiduo Kyai, Jakarta : LP3ES. 
Farida, Siti, Pendidikan Karakter Perspektif Islam, Kabilab, Vol. 1 No. 1 Juni 2016.

Fatoni, Acmad. Peran Kyai Pesantren dalam Partai Politik, Yogyakarta: Pustaka Pelajar,2007.

Ghazali, M. Bachri. Pesantren Berwawasan Lingkungan, Jakaarta, CV Prasti.

Ghazali Said, Imam. Kitab-kitab Karya Ulama' Pembaharu: Biografi, Pemikiran dan Pergerakan. Surabaya: PT Duta Aksara Mulia, 2018.

Ghazali, M. Bahri. Pesantren Berwawasan Lingkungan. Jakarta : Cv Prasasti, 2002.

Hasbullah, Kapita Selekta Pendidikan Islam. Jakarta: Grafindo Persada, 1999.

H Makmun. Pembentukan Karakter Berbasis Pendidikan Pesantren: Studi di Pondok Pesantren Tradisional dan Modern Di Kabupaten Ponorogo. Cendekia Vol.,.2014.

Idris, Zahara. Pengantar Pendidikan I Jakarta: Grasindo, 1992.

Imam Syafe'I, Pondok Pesantren: Lembaga Pendidikan Pembentukan Karakter; Aladzkiyyah: Jurnal Pendidikan Islam, Volume 8, No I 2017.

Ibnu Qayyim al Jauziyyah, Imam Syamsuddin Abu Abdillah. al Fawa’id Beirut: Dar al Fikr, 1993.

Kafrawi, Pembaharuan Sistim Pendidikan Pondok Pesantren Sebagai Usaha Peningkatan Prestasi Kerja dan Pembinaan Kesatuan Bangsa, Jakarta: PT. Cemara Indah,1978..

Khusnurridho, M. Shulton. Manajemen Pondok Pesantren dalam Persepektif Global, Yogyakarta : LaksbangPressIndo, 2006.

Madjid, Nurcholish Bilik-Bilik Pesantren. Jakarta :Dian Rakyat.

Majid, Fakhry. Ethical Theories in Islam Leiden: E. J. Brill, 1991.

Ma'luf, Luis. al Munjid fi al Lughah wa al-'alam. Beirut: Dar al Masyriq, 2002. 
Mastuhu, Dinamika Sistem Pendidikan Pesanten: Suatu Kajian tentang Unsur dan Nilai Sistem Pendidikan Pesantren. Jakarta: INIS,1994.

Maunah, Binti. Traduisi Intelektuaal Santri Dalaam Tantangan dan Hambaatan Pendidikan Pesantren di Masa Depan,Yogyakaarta Teras 2009.

Manz\} ur, Jamaluddin. Lisa>n al 'Arab.Beirut: Dar S\}a >dir, 1414 H, Jilid X.

Muchlis Solichin, Mohammad. Keberlangsungan dan Perubaban Pendidikan Pesantren di Tengah Arus Modernisasi Pendidikan Surabaya: CV. Salsabila Putra Pratama, 2013.

Muhakamurrohman, Ahmad. Pesantren Santri,Kiai,dan Tradisi, Vol. 12, No.2,JuliDesember 2014.

Mochtar, Masyhuri. Dinamika Kajian Kitab Kuning di Pesantren. Pasuruan: Pustaka Sidogiri, 1434.

Moctar, Affandi. Kitab Kuning dan Tradisi Akademik Pesantren. Jawa Barat: Pustaka Isfahan,2009.

Rahardjo, Dawam. Pergulatan Dunia Pesantren, Membangun dari Bawah, Jakarta:P3M,1985.

Rosif, "Pendidikan Etika dan Kepribadian; Studi atas Pemikiran Sayyid Naquib al Attas dan Ibn Miskawayh", dalam Antologi Kajian Islam, ed. Husein Aziz, et al. Surabaya: Pascasarjana UIN Sunan Ampel Surabaya, 2016.

Sahlan. Asmaun. Pendidikan Karakter dalam Perspektif Islam. Kajian Penerapan Pendidikan Karakter di Lembaga Pendidikan Islam, 2013 El-HiKMAH, 9.

Sarkawi, Sistem Pembelajaran Pondok Cilik Maktab Nubdzatul Bayan Mambaul Ulum Bata-Bata Pamekasan, Tadris Volome 7 Nomor 2 Desember 2012.

Saputra, Mundzier. Perubahan Orientasi Pondok Pesantren Salafiyab Terbadap Perilaku Keagamaan Masyarakat. Jakarta:Asta Buana Sejahtera,2009.

Sayyid Thanthawi, Muhammad. al Aqidab wa al Akblaq. Mesir: Nahdhatu Mishra, t.th 
Sholeh dkk, Badrus. Budaya Damai Komonitas Pesantren. Jakarta: Pustaka LP3ES Indonesia,2007.

Shaliba, Jamil. al-Mu'jam al Falsafi. Mesir: Dar al Kitab al Misri, 1978. Jilid I, 539.

Soebahar,Abd. Halim. Modernisasi Pesantren. Yogyakarta: YKiS, 2013.

Tafsir, Ahmad. Metodologi Pengajaran Agama Islam. Bandung: PT Remaja Rosdakarya, 2017.

Poerwadarminta, W. J. S. Kamus Besar Bahasa Indonesia. Jakarta: Balai Pustaka, 1985.

Ya'qu $>$ b Miskawaih, Muh $\}$ ammad. Tab\} dhib al Akbla $>$ q wa Tabbi $>$ ral 'Ara $>q$ (t.tp: Maktabah al-Thaqa $>$ fah al Di $>$ niyyah, t.t.

Wahid, Abdurrahman. Menggerakekan tradisi esaai-esai pesantren, Yogyakarta : LkiS, 2001.

Ziemek, Manfred. Pesantren dalam Perubahan Sosial, Terjemahan Butche B. Soendjojo, Jakarta: P3M, 1983. 